\title{
Cutaneous Presentation of Follicular Lymphomas
}

Renato Franco, M.D., Amalia Fernández-Vázquez, M.D., Manuela Mollejo, M.D., Miguel A. Cruz, M.D., Francisca I. Camacho, M.D., Juan F. García, M.D., Mercedes Navarrete, B.Sc., Miguel A. Piris, M.D.

Department of Biomorphological and Functional Science, Federico II University of Napoli, Italy (RF); Department of Molecular Pathology, Centro Nacional de Investigaciones Oncologicas Carlos III, Majadahonda-Madrid (AFV, FIC, JFG, MN, MAP), Madrid, Spain; and Departments of Pathology (MM) and Oncology (MAC), Virgen de la Salud Hospital, Toledo, Spain

The description of primary cutaneous follicular lymphoma has raised interest in the differential diagnosis of this versus disseminated follicular lymphoma involving the skin. We report here on four cases of Stage IV follicular lymphoma, diagnosed in skin biopsy, in which cutaneous lesion was the most noticeable feature of clinical presentation. In all cases, the morphological features were superimposed over typical nodal follicular lymphoma. Apart from classic B-cell markers, they were characterized by $\mathrm{CD} 10$ and bcl6 positivity, markers of follicle germinal center cells; and bcl2 expression, with a corresponding $t(14 ; 18)$ translocation in three of three cases examined. In all four cases, bone marrow study and clinical staging revealed disease that had disseminated since diagnosis. Follow-up showed relapsing cutaneous and nodal disease in two cases. The only difference observed with a control group of 10 cases of primary cutaneous follicular lymphoma was the absence in this group of $t(14$; 18). Disseminated classical follicular lymphoma has to be considered in the differential diagnosis of follicular lymphoma presenting in the skin. This series of cases suggests that the presence of $t(14 ; 18)$ could imply the existence of disease that has disseminated beyond the skin and that cases harboring this translocation could be candidates for systemic polychemotherapy.

KEY WORDS: bcl2, bcl6, CD10, Follicular lymphoma, Primary cutaneous follicular lymphoma, Translocation $(14 ; 18)$.

Mod Pathol 2001;14(9):913-919

Copyright $(\odot 2001$ by The United States and Canadian Academy of Pathology, Inc.

VOL. 14, NO. 9, P. 913, 2001 Printed in the U.S.A.

Date of acceptance: March 30, 2001.

This work was supported by Grant IFD97-0431 from the Ministerio de Educacion y Ciencia, Spain.

Address reprint requests to: Miguel A. Piris, Centro Nacional de Investigaciones Oncologicas Carlos III, Carretera Majadahonda-Pozuelo, km. 2, 28220 Majadahonda, Madrid, Spain; e-mail: mapiris@cnio.es; fax:-34-91-509-70-55.
The morphological features and clinical behavior of B-cell lymphomas presenting in the skin are scarcely recognized in the lymphoma classification currently in use, the REAL classification (1), which has led to the publication of a first proposal of cutaneous lymphoma by the EORTC group (2). One of the groups included in this category, so-called cutaneous follicular lymphoma (CFL), has fueled a debate on the features and differential nature of this entity. Although the molecular, phenotypical, and morphological traits of these tumors have yet to be fully defined, the concept that some bona fide B-cell lymphomas originating in the lymphoid follicle may clinically present as cutaneous tumors seems to be clearly established (2-4). Thus the skin could be involved by follicular lymphoma (FL), in the form of a secondary lesion (sCFL), the expression of disseminated disease, or as a primary lesion (pCFL), localized initially in the skin and usually for a long period of time (2-5).

Systemic FL is usually a disseminated neoplasm, with over two thirds of cases being in Stage III or IV at diagnosis (2). It recapitulates both the cytological and immunohistochemical features of secondary follicles, and neoplastic cells frequently show a specific translocation, $\mathrm{t}(14 ; 18)$. It may also involve the skin in the form of specific lesions, sCFL, and does so in almost $4 \%$ of cases (4).

The existence of primary cutaneous B-cell lymphoma, defined as a B-cell non-Hodgkin's lymphoma primarily occurring in and remaining confined to the skin for a period of at least 6 months, has now been widely accepted (2, 5, 7-21). According to the EORTC, primary cutaneous follicular lymphoma (pCFL) shows a relatively good outcome, rarely disseminating to extracutaneous sites. This could support the selection of local treatment of the tumor $(2,4,19,22,23)$. The real frequency of pCFL and its morphological and molecular characteristics are, however, a matter of controversy, as are its differential diagnosis versus marginal zone 
lymphoma in the skin $(7,24)$ and disseminated FL involving the skin.

In the course of a review of cases of cutaneous B-cell lymphoma, we noticed the existence of a group of four cases of FLs that, diagnosed on the basis of skin biopsies, have shown widespread disease since diagnosis, with clinical signs of progression in at least two cases. Because this suggests that these tumors must be recognized independently of pCFL, we reviewed the main features of this group of FLs presenting in the skin.

\section{MATERIALS AND METHODS}

\section{Patients and Tissue Samples}

Tumor specimens of four cutaneous biopsies with FL were obtained from routine files of the Virgen de la Salud Hospital, Toledo, Spain, corresponding to a period from 1990 to 2000 . All patients were under study for cutaneous lesions that at biopsy showed FL histology. From the onset of the disease, the staging of all the patients included in the series showed widespread involvement, including bone marrow infiltration. All specimens were reevaluated, including initial cutaneous lesions, the staging bone marrow biopsies, secondary cutaneous lesions, or restaging bone marrow biopsies performed during the follow-up. Cases were classified into three grades, based on numbers of large cells (centroblasts), according to the criteria of Mann and Bernard (25)

\section{Immunohistochemistry}

All immunostaining techniques were performed in paraffin-embedded tissue sections, using a previous step of heat-induced antigen retrieval technique for all antibodies. Thus, before incubation with the primary antibody, slides were heated in a pressure cooker for 3 minutes in a solution of 0.01 $\mathrm{mol} / \mathrm{L}$ sodium citrate.

After incubation with the antibody, immunodetection was performed with biotinylated antimouse immunoglobulins, followed by peroxidase-labeled streptavidin (LSAB-DAKO, Glostrup, Denmark) with diaminobenzidine chromogen as substrate. All immunostaining was performed using the Techmate 500 (DAKO) automatic immunostaining device. The antibodies used for immunohistochemical study were directed against B-cell markers CD20 and CD79a, T-cell marker CD3; specific markers of mantle-cell lymphoma CD5, cyclin D1, and IgD; germinal center markers such as CD10 and bcl6; marker of dendritic cells CD23; oncoproteins p53 and bcl2; and proliferative marker MIB1. The data corresponding to the antibodies used are shown in Table 1.
TABLE 1. Characteristics of Antibodies

\begin{tabular}{llcc}
\hline Antigen & Clone (Manufacturer) & Incubation Time & Dilution \\
\hline CD20 & L26 (DAKO) & $40 \mathrm{~min}$ & $1: 50$ \\
CD79a & JCB117 (DAKO) & $40 \mathrm{~min}$ & $1: 25$ \\
CD23 & MHM6 (DAKO) & $40 \mathrm{~min}$ & $1: 25$ \\
CD10 & 56C6 (Novocastra) & Overnight & $1: 25$ \\
CD3 & Polyclonal (DAKO) & $40 \mathrm{~min}$ & $1: 50$ \\
CD43 & DFT1 (DAKO) & $40 \mathrm{~min}$ & $1: 50$ \\
CD5 & 4C7 (Novocastra) & $40 \mathrm{~min}$ & $1: 10$ \\
CiclD1 & DC56 (DAKO) & $40 \mathrm{~min}$ & $1: 100$ \\
P53 & DO7 (DAKO) & $40 \mathrm{~min}$ & $1: 50$ \\
Bcl2 & 124 (DAKO) & $40 \mathrm{~min}$ & $1: 25$ \\
Bcl6 & PG-B6P (DAKO) & $40 \mathrm{~min}$ & $1: 10$ \\
MIB1 & MIB1 (Immunotech) & $40 \mathrm{~min}$ & $1: 50$ \\
\hline
\end{tabular}

The presence of positivity was quantified as a percentage. In particular, CD20, CD10, bcl6, and bcl2 were scored as positive if the majority of tumoral cells showed a distinct reactivity. MIB1 expression was scored as low Ki67 when the percentage of positive tumoral cells was $<30 \%$; moderate when between $30 \%$ and $60 \%$; and high when $>60 \%$ of tumoral cells were positive.

\section{Polymerase Chain Reaction}

DNA isolated by conventional methods from peripheral blood (Case 3), bone marrow and peripheral blood (Case 2), and cryopreserved $\left(-80^{\circ} \mathrm{C}\right)$ tissue of skin biopsies was analyzed for $\mathrm{t}(14 ; 18)$ by polymerase chain reaction (PCR). PCR amplification of p53 Exon 8 (249 bp) was used to assess the suitability of DNA extracts, using a volume of 100 ng.

PCR was performed to detect the $t(14 ; 18)$ at the major breakpoint region (MBR). PCR was performed with $0.1 \mu \mathrm{g}$ of purified DNA, which was subjected to 35 cycles of PCR amplification using MBR and JH consensus primer. The MBR and JH primers have been described elsewhere (21). Ten percent of PCR products was size-fractionated on $1.5 \%$ agarose gel. Specimens were observed in ultraviolet B light. The presence of a band between 100 and 250 base pairs (bp) was considered positive for translocation.

\section{Controls}

A group of 10 cases of pCFL was used as the control group for the study of $t(14 ; 18)$. These cases were selected according to clinical findings (computed tomography scan, ultrasonography, and bone marrow biopsies without signs of lymphoma involvement for at least 6 months after diagnosis), morphological signs (follicular pattern of growth, germinal center cytology), immunophenotypical criteria (bcl6 and CD10 positivity and the presence of follicular dendritic cells), and suitability of the DNA extracted from paraffin-embedded tissue for PCR analysis. Samples were from a larger collection 
of cutaneous pCBCL obtained from the files of the Spanish hospitals integrated in the Spanish Lymphoma Club. These cases of pCFL belong to a larger series, whose results concerning the frequency of IgH rearrangement and $\mathrm{t}(14 ; 18)$ translocation have already been published (26).

\section{RESULTS}

\section{Clinical features}

The main clinical data are shown in Table 2.

\section{Case 1}

This was a female 61-year-old showing several erythematous lesions of $>0.5 \mathrm{~cm}$ on the left eyebrow (Fig. 1) and in the sternal region, with other smaller ones spread over the trunk. No other symptoms were present. Twelve months after the initial symptoms, a biopsy of the lesions was performed and showed the features of FL. Laboratory examination did not provide significant results. Clinical examination revealed significant axillary and inguinal adenopathy (node size, $>1.0 \mathrm{~cm}$ ), and radiological examination (computed tomography scan and ultrasonography) showed hepatosplenomegaly. Bone marrow biopsy also showed a neoplastic infiltration. The patient was classified as having Stage IV FL.

She was treated with polychemotherapy and had a complete remission. She was well with the exception of nonspecific remittent lymphadenopathy for a period of 50 months, when three erythematous infiltrated lesions were observed in the posterolateral region of the right thigh. Bone marrow biopsy was negative. X-ray exams were negative. Biopsy showed FL in this case. The patient began to receive local radiotherapy.

Fifteen months later, another papule was observed in the exterior upper left leg, and the biopsy again showed FL. Finally, 14 months later, another lesion positive for FL was observed in the antero- lateral region of the left leg. Radiotherapy was performed.

Eight years after diagnosis, the patient is alive, with disease restricted to the skin.

\section{Case 2}

This female 33-year-old presented a solitary papule of the scalp, surrounded by an annular erythema. No other symptoms were present. One year after the initial symptom, a skin biopsy showed lesions diagnosed as FL. Laboratory examination was not significant. Clinical and x-ray examination results were negative for other site locations. Bone marrow biopsy showed FL infiltration. A $\mathrm{t}(14 ; 18)$ was then detected in peripheral blood and bone marrow lymphocytes. The patient had a complete clinical remission, with persistence of $t(14 ; 18)$ in peripheral blood.

Thirty-two months later, she showed weight loss (5 kg) and irregularities of the menstrual cycle. Retroperitoneal lymphadenopathies and a peritoneal mass were found at this time by CT scan. This time, the patient was treated with polychemotherapy, and she underwent clinical and molecular remission. Now, 60 months after the initial diagnosis, she is alive and well.

\section{Case 3}

This 49-year-old woman presented a cutaneous nodule on the right shoulder and a smaller one in the sternal region. No symptoms were present. Ten months after the initial symptoms, cutaneous biopsy showed an FL. Subsequent clinical examination showed significant axillary and inguinal lymphadenopathies. CT scan and ultrasonography did not show any significant alterations. Bone marrow biopsy showed neoplastic infiltration. $t(14 ; 18)$ was detected in bone marrow lymphocytes. The patient was considered to be in Stage IV of the disease. After 5 months of polychemotherapy, she still has persistent disease.

TABLE 2. Main Clinical Data

\begin{tabular}{|c|c|c|c|c|c|}
\hline Case & $\begin{array}{l}\text { Site Primitive Lesion } \\
\text { (Duration in Months of } \\
\text { Clinical Symptoms } \\
\text { before Biopsy) }\end{array}$ & $\begin{array}{l}\text { Other Sites of Disease at } \\
\text { Staging }\end{array}$ & $\begin{array}{l}\text { Therapy after } \\
\text { Surgical } \\
\text { Excision }\end{array}$ & $\begin{array}{c}\text { Follow-Up (Tissues Infiltrated and } \\
\text { Time from the Diagnosis, in } \\
\text { Months) }\end{array}$ & $\begin{array}{l}\text { Status (Months } \\
\text { from Diagnosis) }\end{array}$ \\
\hline 1 & $\begin{array}{l}\text { Right eyebrow sternal } \\
\text { region (10) }\end{array}$ & $\begin{array}{l}\text { Liver and spleen; axillary } \\
\text { LNs; bone marrow }\end{array}$ & СТ & $\begin{array}{l}\text { Bone marrow }(0,7) \text {; liver, spleen } \\
\text { and axillary LNs }(0,7) \text {; skin, } \\
\text { right thigh }(71) \text {; skin, left leg } \\
\text { (88); skin, left leg (91) }\end{array}$ & AWD (108) \\
\hline 2 & Scalp (12) & Bone marrow & СТ & $\begin{array}{l}\text { Bone marrow }(0,7) \text {; intercavo- } \\
\text { aortic LNs and peritoneum (48) }\end{array}$ & CR (60) \\
\hline 3 & Right shoulder (10) & $\begin{array}{l}\text { Neck and axillary LNs; } \\
\text { bone marrow }\end{array}$ & СТ & $\begin{array}{l}\text { Bone marrow }(0) \text {; neck and } \\
\text { axillary LNs }(0)\end{array}$ & AWD (5) \\
\hline 4 & Frontal region $(60)$ & Bone marrow & RT & Bone marrow $(0)$ & CR (36) \\
\hline
\end{tabular}

All cases were Stage IV and female.

CT, chemotherapy; RT, radiotherapy; AWD, alive with disease; CR, complete remission; LN, lymph node. 


\section{Case 4}

A female 74-year-old presented a 5-year-old cutaneous nodule with slow growth in the right frontal region, associated with smaller peripheral papules. B symptoms were not present. Skin biopsy showed FL. Laboratory examinations were not significant. Clinical and x-ray examinations were negative. Bone marrow biopsy showed an infiltration of lymphoma. The patient was considered to be at Stage IV.

In consideration of her age and of the absence of other lesions, the patient was submitted to local radiotherapy. After 7 months, the patient finished radiotherapy, and cutaneous lesions disappeared. The patient is now alive and well 3 years after diagnosis.

\section{Histological Findings}

\section{Skin samples}

In all cases, we observed a middermal and subcutaneous diffuse and/or nodular infiltration by germinal center B cells, composed of confluent nodules of variable size. The tumoral cells were represented in variable amounts in each case by small, cleaved cells and large cells, cleaved or noncleaved, and with a prominent nucleolus. In particular, we observed prevalent centrocytes (Grade I FL) in Case 1; a mixture of centrocytes and centroblasts (Grade II FL) in Cases 2 and 3; and a prevalent population of centroblasts (Grade III FL) in the fourth case. A variable component of reactive $\mathrm{T}$-cells was also observed in each case. No reactive follicles were observed. The papillary dermis was spared in all cases in the typical Grenz zone fashion, as well as was the epidermis. No epidermotropism was observed (Table 3 and Fig. 2).

No appreciable changes were observed in the consecutive biopsies of these patients, except for a transformation of histological grade in Case 1, in which a transition to Grade II was observed during relapses.

\section{Bone marrow biopsy}

Bone marrow biopsies performed for the staging of disease showed a paratrabecular, nodular infiltration by FL in all cases, whereas in Case 4, the presence of diffuse bone marrow involvement was also observed. The cytology was composed mainly of small B cells (Fig. 3). Follow-up bone marrow biopsies in Case 1 showed persistent infiltration, despite treatment.

\section{Immunohistochemical findings}

Neoplastic cells showed a B-cell immunophenotype (CD20+, CD79a+, CD3- CD43-) in skin specimens and bone marrow biopsies in all cases. CD10, bcl2, and bcl6 were positive in all cases. Bcl6 expression was observed both in the follicular and interfollicular compartment. All cases were negative for cyclin D1 and CD5. p53 was always negative. MIB1 expression was low to intermediate (Table 3 and Fig. 4). In all cases, neoplastic follicles were outlined by the presence of aggregates of CD23+ follicular dendritic cells.

Bone marrow biopsy showed CD20 and bcl2positive paratrabecular nodules (Fig. 3b).

\section{PCR findings}

In the group of disseminated FL presenting in the skin, PCR study detected the presence of $t(14 ; 18)$ in all three cases in which DNA was available for molecular study. This study was performed in the cutaneous samples in two of three cases, whereas in the third case, it was done using peripheral blood and bone marrow. The quality of the DNA extracted in Case 4 was unsuitable for molecular study (Table 3 and Fig. 5). None of the 10 cases of pCFL showed $\mathrm{t}(14 ; 18)$.

\section{DISCUSSION}

We described four cases of Stage IV FL presenting in the skin. All four of these cases showed bone marrow infiltration at initial diagnosis, and two of them displayed lymph node involvement. Despite this, the clinical follow-up revealed a relatively indolent clinical behavior, with relapses in two of four cases. To the best of our knowledge, cases such as these, disseminated FL in which the first clinical manifestation was cutaneous infiltration, have not been reported previously, and they may raise difficulties in terms of differential diagnosis between sCFL and pCFL. Cases so far reported of FL with cutaneous infiltration antecede the recognition that B-cell lymphoma may debut as a purely cutaneous tumor, differentiating them from rare cases of concurrent involvement of lymph node and skin at

TABLE 3. Main Morphological and Immunohistochemical Findings in Secondary Cutaneous Follicular Lymphoma

\begin{tabular}{|c|c|c|c|c|c|c|c|c|}
\hline Case & Grade & $\mathrm{CD} 20$ & CD10 & $\mathrm{Bcl} 2$ & Bcl6 & P53 & Ki67 & $\mathrm{t}(14 ; 18)$ \\
\hline 1 & I & + & + & + & + & - & Low & + \\
\hline 2 & II & + & + & + & + & - & Low & + \\
\hline 3 & II & + & + & + & + & - & Low & + \\
\hline 4 & III & + & + & + & + & - & Intermediate & ND \\
\hline
\end{tabular}

ND, not determined. 


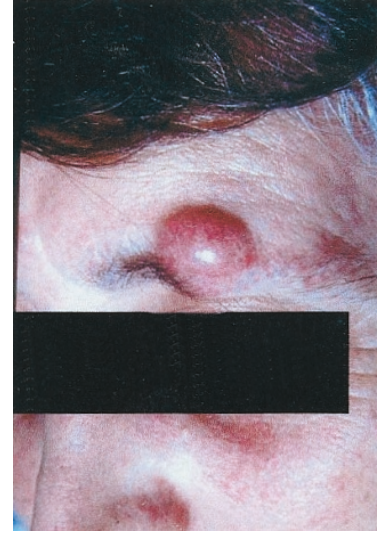

FIGURE 1. Nodular lesion at left eyebrow.

diagnosis (27) or from secondary cutaneous involvement in the course of the disease $(5,27)$.

Cutaneous lymphomas represent the second most important group of extranodal lymphomas after gastrointestinal lymphoma $(2,17,20)$. Until recent years, no real distinction between pCFL and sCFL was made, and they were all classified, and therefore treated, according to the scheme used for nodal non-Hodgkin's lymphoma $(28,29)$. So-called primary cutaneous lymphoma, because of its peculiar clinicopathological features, has recently been the subject of specific proposals for classification (2, $7,20,23)$. The aim of recently introduced classifications, such as the Revised European American Lymphoma classification (1) and that by the European Organization for Research and Treatment (2), is to differentiate distinct nosological entities with peculiar clinical characteristics. In the staging and treatment of patients with cutaneous lymphoma, the usefulness of distinguishing lymphoma restricted to the skin from other generalized lymphomas involving the skin is of great practical importance.

We have shown here that disseminated FL debuted with only symptomatic and often prolonged cutaneous lesions, the initial diagnosis being performed with a skin biopsy. Only after the initial diagnosis of lymphoma was made did the staging of the patient reveal widespread disease, including bone marrow infiltration in all cases $(2,6)$. This emphasizes the usefulness of including a bone marrow biopsy in the staging of cutaneous lymphoma before making a diagnosis of primary cutaneous lymphoma.

Disseminated FL has a 5-year survival probability of 30 to $50 \%$ and needs to be treated with general polychemotherapy. This contrasts with data showing that in pCFL, the probability of survival is well above $90 \%$ after a 10 -year follow-up $(2,4)$. This difference in survival probability and treatment underscores the importance of finding molecular or immunophenotypic markers that can distinguish
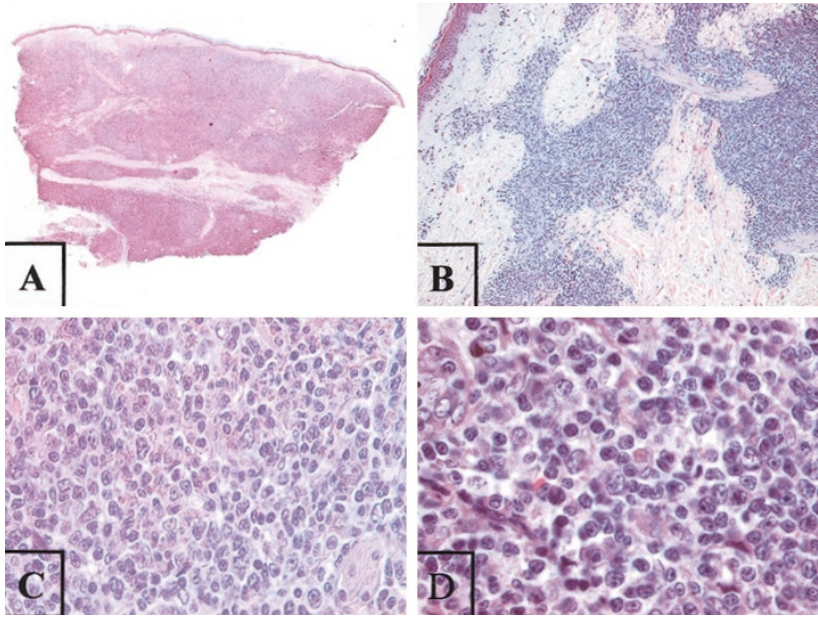

FIGURE 2. Hematoxylin-eosin staining. Nodular pattern of dermal infiltration of lymphoma $(\mathbf{A}, 10.6 \times ; \mathbf{B}, 250 \times)$ with representation of centrocytes and centroblasts $(\mathbf{C}, 630 \times$; D, 1000×).

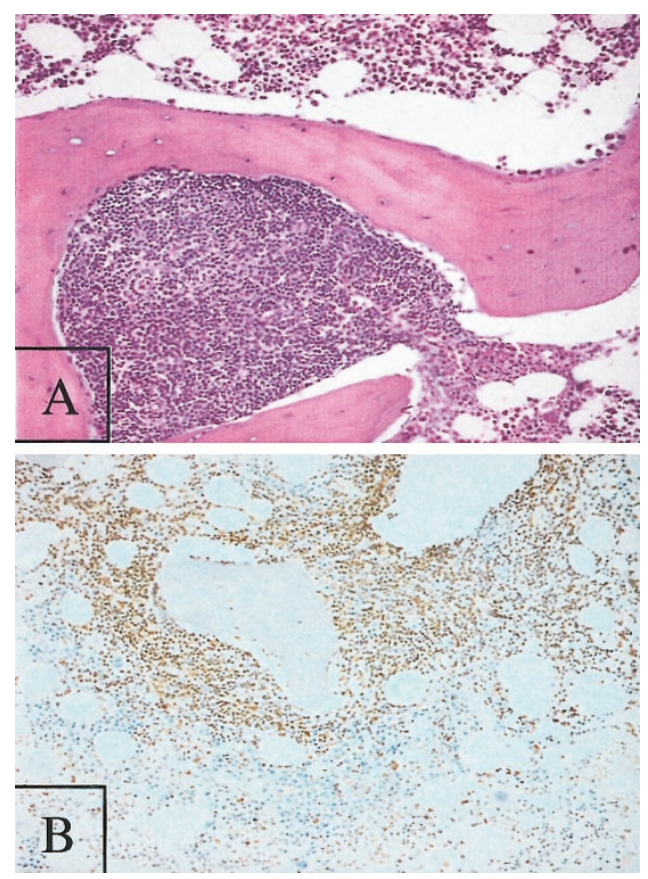

FIGURE 3. A, paratrabecular bone marrow infiltration by lymphoma (hematoxylin-eosin staining, $200 \times$ ). B, bcl2 positivity of bone marrow neoplastic cells $(200 \times)$.

between these two different clinical presentations of FL. Although pCFLs display the same morphology and CD10 or bcl6 expression as nodal FL, they may differ in the incidence of $t(14 ; 18)$, which has only rarely been reported in pCFL $(4,12,24,31)$. Thus, in our series, $t(14 ; 18)$ was present in three of three cases analyzed, in contrast with its absence in 10 of 10 of the cases of pCFL included here for comparison. The absence of a $t(14 ; 18)$ in pCFL is consistent with the findings by Cerroni et al. (4), who recently described a series of 15 pCFL that were diagnosed and staged according to classical criteria. Other authors show the presence of this $t(14 ; 18)$ in a proportion of patients; thus, Volk- 

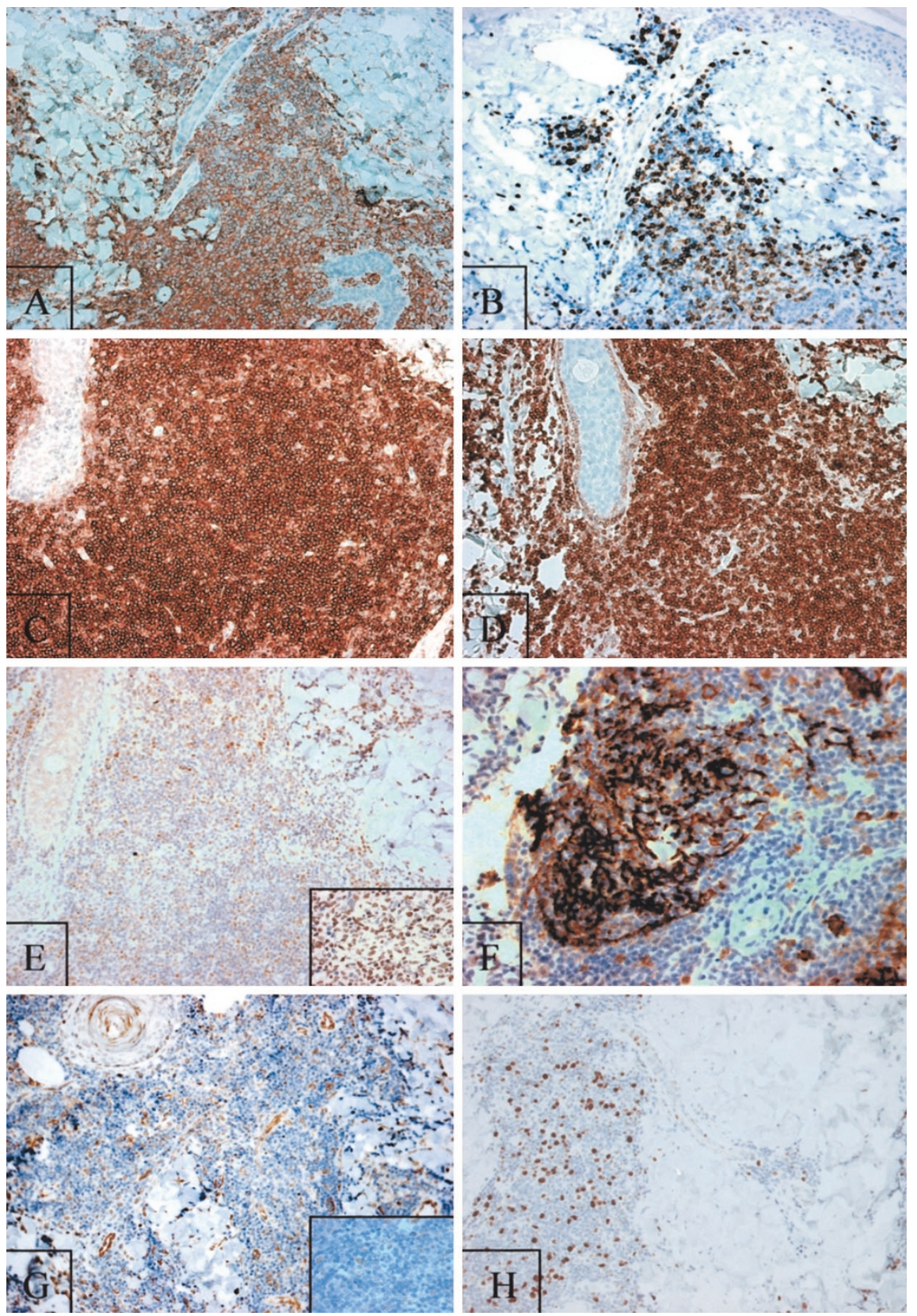

FIGURE 4. Immunohistochemistry. A, CD20 (200×). B, CD3 $(200 \times)$. C, CD10 ( $200 \times)$. D, bcl2 $(200 \times)$. E, bcl6 (200× and detail, $450 \times)$. F, CD23 $(200 \times)$. G, IgD $(200 \times$ and detail, $450 \times)$. H, MIB1 $(200 \times)$.

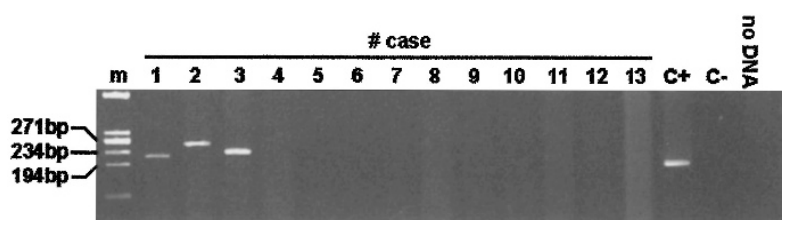

FIGURE 5. Polymerase chain reaction results. Cases 1 to 3: secondary cutaneous follicular lymphoma. Cases 4 to 13: primary cutaneous follicular lymphoma. The band indicates the presence of $t(14 ; 18)$ in Cases 1 to 3. $\mathrm{C}+$, positive control. $\mathrm{C}-$, negative control.

enandt et al. (30) describe this translocation in 1 case of 10 centroblastic and centrocytic lymphomas, and Yang et al. (31) describe a very high frequency of $t(14 ; 18)$ in pCFL $(6 / 15$ cases $)$. Whether these differences could be attributable to variations in the procedure for clinical staging of the patients or the conditions used in molecular study remains to be answered, but in any case, the data here showed are consistent with the findings reported by Cerroni et al. (4) correlating the presence of $\mathrm{t}(14 ; 18)$ with disseminated extracutaneous disease.

Nevertheless, all of these data suggest that it would be advisable to perform additional biological studies on larger groups of patients with different types of cutaneous lymphoma to better define the boundary between primary and secondary cases (2).

To conclude, we underline the fact that FL, when diagnosed in the skin, may correspond to cutane- 
ous preferential involvement by disseminated FLs. The data collected here seem to support the interest of recognizing these tumors, given that they have shown a tendency to involve extracutaneous sites and relapse in nodal and other locations. A particular contribution to clinical staging was made by the performance of bone marrow biopsy. Our findings also indicate the clinical relevance of the presence of a $t(14 ; 18)$, which was always found to be associated with disseminated extracutaneous disease in this study.

\section{REFERENCES}

1. Harris NL, Jaffe ES, Stein H, Banks PM, Chan JK, Cleary ML, et al. A revised European-American classification of lymphoid neoplasms: a proposal from the International Lymphoma Study Group. Blood 1994;84:1361-92.

2. Willemze R, Kerl H, Sterry W, Berti E, Cerroni L, Chimenti S, et al. EORTC classification for primary cutaneous lymphomas: a proposal from the Cutaneous Lymphoma Study Group of the European Organization for Research and Treatment of Cancer. Blood 1997;90:354-71.

3. Bastion Y, Berger F, Bryon PA, Felman P, Ffrench M, Coiffier B. Follicular lymphomas: assessment of prognostic factors in 127 patients followed for 10 years. Ann Oncol 1991;2S:123-9.

4. Cerroni L, Arzberger E, Pütz B, Höfler G, Metze D, Sander CA, et al. Primary cutaneous follicle center cell lymphoma with follicular growth pattern. Blood 2000;95:3922-8.

5. Dabski K, Banks PM, Winkelmann RK. Clinicopathologic spectrum of cutaneous manifestations in systemic follicular lymphoma: a study of 11 patients. Cancer 1989;64:1480-5.

6. Armitage JO, Weisenburger DD. New approach to classifying non-Hodgkin's lymphomas: clinical features of the major histologic subtypes. Non-Hodgkin's Lymphoma Classification Project. J Clin Oncol 1998;16:2780-95.

7. Aarts WM, Willemze R, Bende RJ, Meijer CJ, Pals ST, van Noesel CJ. VH gene analysis of primary cutaneous B-cell lymphomas: evidence for ongoing somatic hypermutation and isotype switching. Blood 1998;92:3857-3864.

8. Baldassano MF, Bailey EM, Ferry JA, Harris NL, Duncan LM. Cutaneous lymphoid hyperplasia and cutaneous marginal zone lymphoma: comparison of morphologic and immunophenotypic features. Am J Surg Pathol 1999;23:88-96.

9. Beljaard RC, van Beek P, Willemze R. Relation between expression of adhesion molecules and clinical behaviour in cutaneous follicle centre cell lymphomas. J Am Acad Dermatol 1997;37:34-40.

10. Cerroni L, Kerl H. Diagnostic immunohistology: cutaneous lymphomas and pseudolymphomas. Semin Cutan Med Surg 1999;18:64-70.

11. Cerroni L, Signoretti S, Hofler G, Annessi G, Putz B, Lackinger E, et al. Primary cutaneous marginal zone B-cell lymphoma: a recently described entity of low-grade malignant cutaneous B-cell lymphoma. Am J Surg Pathol 1997;21:130715.

12. Cerroni L, Volkenandt M, Rieger E, Soyer HP, Kerl H. bcl-2 protein expression and correlation with the interchromosomal 14; 18 translocation in cutaneous lymphomas and pseudolymphomas. J Invest Dermatol 1994;102:231-5.

13. Delia D, Borrello MG, Berti E, Pierotti MA, Biassoni D, Giannotti $\mathrm{R}$, et al. Clonal immunoglobulin gene rearrange- ments and normal T-cell receptor, bcl2, and c-myc genes in primary cutaneous B-cell lymphomas. Cancer Res 1989;49: 4901-5.

14. Faure P, Chittal S, Gorguet B, Caveriviere P, Brousset P, Viraben $\mathrm{R}$, et al. Immunohistochemical profile of cutaneous B-cell lymphoma on cryostat and paraffin sections. Am J Dermatopathol 1990;12:122-33.

15. Garbe C, Stein H, Dienermann D, Orfanos CE. Borrelia Burgdorferi associated cutaneous B cell lymphoma: clinical and immunohistologic characterization of four cases. J Am Acad Dermatol 1991;125:373-86.

16. Giannotti B, Santucci M. Skin-associated lymphoid tissuerelated B-cell lymphoma (primary cutaneous B-cell lymphoma). Arch Dermatol 1993;129:353-5.

17. Isaacson PG, Norton AJ. Cutaneous lymphoma. In: Isaacson PG, Norton AJ, editors. Extranodal lymphoma. London: Churchill Livingstone; 1994. p. 172.

18. Kempf W, Dummer R, Burg G. Approach to lymphoproliferative infiltrates of the skin. The difficult lesions. Am J Clin Pathol 1999;111(1 Suppl 1):S84-93.

19. Sepp N, Weyer K, Haun M, Zelger B, Thaler J, Faber V, et al. Differentiation of primary and secondary cutaneous B-cell lymphoma by Southern blot analysis. Am J Clin Pathol 1996; 106:749-57.

20. Slater DN. MALT and SALT: the clue to cutaneous B-cell lymphoproliferative disease. Br J Dermatol 1994;131:557-61.

21. Willemze R, Beljaards RC, Meijer CJ, Rijlaarsdam JR. Classification of primary cutaneous lymphomas. Historical overview and perspectives. Dermatology 1994;189(Suppl 2):8-15.

22. Kerl H, Cerroni L. The morphologic spectrum of cutaneous B-cell lymphomas. Arch Dermatol 1996;132:1376-7.

23. Kurtin PJ, Di Caudo DJ, Habermann TM, Chen MG, Su WP. Primary cutaneous large cell lymphomas. Morphologic, immunophenotypic, and clinical features of 20 cases. Am J Surg Pathol 1994;18:1183-91.

24. Willemze R, Rijlaarsdam JU, Meijer CJ. Are most primary cutaneous B-cell lymphomas "marginal cell lymphomas"? Br J Dermatol 1995;133:950-2.

25. Mann RB, Bernard CW. Criteria for the cytological subclassification of follicular lymphomas: a proposed alternative method. Hematol Oncol 1983;1:187-92.

26. Franco R, Fernandez-Vazquez A, Rodriguez-Peralto JL, Bellas C, López-Ríos F, Sáez A, et al. Cutaneous follicular B-cell lymphoma. Description of a series of 18 cases. Am J Surg Pathol 2001;25:875-83.

27. Garcia CF, Weiss LM, Warnke RA, Wood GS. Cutaneous follicular lymphoma. Am J Surg Pathol 1986;10:454-63.

28. The Non-Hodgkin's Lymphoma Pathologic Classification Project. National Cancer Institute sponsored study of classification of non-Hodgkin's lymphomas: summary and description of a working formulation for clinical usage. Cancer 1982;49:2112-35.

29. Stansfeld AG, Diebold J, Kapanaci Y, Kelenyi G, Lennert K, Mioduszewska O, et al. Updated Kiel classification for lymphomas. Lancet 1988;1:292-3.

30. Volkenandt M, Cerroni L, Rieger E, Soyer HP, Koch O, Wienecke R, et al. Analysis of the 14; 18 translocation in cutaneous lymphomas using the polymerase chain reaction. J Cutan Pathol 1992;19:353-6.

31. Yang B, Tubbs RR, Finn W, Carlson A, Peatty J, Hsi ED. Clinicopathologic reassessment of primary cutaneous B-cell lymphomas with immunophenotypic and molecular genetic characterization. Am J Surg Pathol 2000;24:694-702. 